in part, by their difficulty in manœuvring for space. It was extremely difficult for all three fish to be completely at the surface at one time.

The fish were returned to the running-water pool after $1.5 \mathrm{hr}$. In the pool they continued to stay at the surface, moving about but not going to the bottom at all. $2 \mathrm{hr}$. later thoy were still at the surface. Normal carp cluster at the bottom even when food is introduced: the fish affected by LSD-25 ignored food scattered in the pool.

Preliminary experiments have shown that Eastern brook trout did not react to LSD-25 in a similar manner to carp.

Experiments with LAE-32 showed that $2 \mu \mathrm{gm}$. per ml. also induced surfacing behaviour of large carp, but this compound takes longer to act and the carp did not remain as consistently at the surface as with a similar concentration of LSD-25.

The mechanism of action of LSD-25 on carp is unknown. As we have shown previously ${ }^{6}$, certain oxidase poisons like sodium azide act in the same way as LSD-25 on Siamese fighting fish. The surfacing behaviour of Siamese fighting fish may also be readily brought about by simple anoxia. It would appear that LSD-25 probably acts by poisoning one of the many oxidase systems which are found in living tissue, as the action of LSD-25 occurs whether it is injected intraperitoneally or placed in the external liquid. As a matter of fact, the regression lines for the reaction-dose curves of LSD-25, whether in the external liquid or injected, and the curves for injected psiloeybin, are all parallel (Abramson, unpublished work).

Experiments in larger tanks, and field trials, are planned to investigate the surfacing behaviour and the edibility of fish exposed to compounds like LSD-25 and LAE-32.

This research was supported, in part, by a grant from Sandoz Pharmaceuticals, Hanover, N.J.

1 Loeb, H. A., and Kelly, W. H., New York Fish and Game Journal, $7,160(1960)$.

${ }^{2}$ Loeb, H. A., New York Fish and Game Journal, 2, 220 (1955); 4, 109 (1957) (personal communication).

${ }^{3}$ Abramson, II. A., Rolo, A., Sklarofsky, B., and Stache, J., $J$. Psychol., 49, 151 (1960).

4 Abramson, H. A., and Evans, I. T., Science, 120, 990 (1954).

5 Evans, L. T., Geronimus, L. H., Kornetsky, C., and Abramson, H. A., Science, 123, 26 (1956).

- Abramson, H. A., Weiss, B., and Baron, M. O., Nature, 181, 1136 (1958).

\title{
OBITUARIES
}

\section{Dr. H. H. Mann}

THe death on December 2 of Harold Hart Mann ended a life of research, remarkable alike for the varied subjects on which he left his mark and for the enthusiasm with which he carried on his work up to his death at the age of eighty-nine. He took his degree in chemistry from the Yorkshire College, later to become the University of Leeds, after which his interest in microbiology took him to the Pasteur Institute in Paris on the award of an 1851 Exhibition, where his work resulted in his first scientific paper, dealing with the effect of antiseptics on the growth of yeast. This also led to his first post, which he held for five years from 1895, that of assistant in chemistry and microbiology to Dr. J. A. Voelker, chemist to the Royal Agricultural Society and director of the Experimental Station at Woburn that was set up by the Society under the patronage of the Duke of Bedford.

This appointment gave Mann a lasting interest and affection for the Station, to which he was to return in later years. He went to India in 1900 as scientific adviser to the Indian Toa Association, later becoming principal of the Poona Agricultural College and agricultural chemist to the Bombay Government, posts which he held until appointed director of agriculture for Bombay Presidency in 1918. During his stay in India his researches on the cultivation of tea and on its diseases and pests revolutionized the culture of this crop, on which he became an accepted authority. Indeed, he acquired a reputation that became almost legendary, and resulted in three visits to the U.S.S.R. between 1930 and 1933 and other visits to countries in East Africa and the Middle East, where his authoritative advice was sought.

Mann returned to Britain in 1928 to take control of the farm and experiments at Woburn Experimental Station, which had recently come under the direction of Rothamsted Experimental Station. At Woburn, as in India, his researches covered a wide field. One of his main interests lay in problems of plant competition. This included competition between plants of the same species, between clover and rye grass and between barley and certain weed species. $\mathrm{H} \Theta$ also carried out experiments for many years on clover sickness and studied the function of organic manures, the effects of green manure crops and leys and the practical possibilities of such erop plants, unusual in Britain, as maize and soy beans. He found time for such investigations in addition to his duties in managing the farm and conducting long-term field experiments which have made the Woburn Station so valuable an adjunct to Rothamsted.

$\mathrm{He}$ continued his active research even after his retirement in 1956 at the age of eighty-four, and was preparing some of his results for publication when he met his death. To the end his inquiring mind remained a source of stimulus to his colleagues, and his infectious enthusiasm, kindliness and generosity will long be remembered by his very numerous friends.

GERARD THORNTON

Harold ManN was one of the last survivors of the band of pioneers who, in the early 1890 's, started to awaken agricultural chemistry from the torpor into which it had fallen in Britain, and setting it on the path which it has since followed with considerable success. His training under Dr. J. A. Voelcker had made him a very careful and conseientious analyst and field experimenter, and his readiness to adopt new ideas and new methods enabled him to make a new approach to old problems, so bringing them nearer to solution.

His studies of tea cultivation cleared the way for much more efficient management, but his work at the Poona Agricultural College and later as director of agriculture in the Bombay Presidency had far wider-reaching effects. It came at a time when great irrigation developments were requiring new and more highly productive systems of cropping and soil management, and with characteristic vigour he 
engaged in the search for them, with very valuable results.

His great services to Indian agriculture are still remembered, but his old students and former Indian colleagues cherish with even greater gratitude the memories of his happy relations with them. In this he was ably supported by his wife, who shared to the full his deep feelings of friendliness and affection for them. She was a lady of great charm and artistic sensibility, a miniaturist of considerable talent, and her house was always open to their Indian friends. This was not customary at that period, a certain reserve between teacher and taught being more usual; but neither he nor she hesitated to depart from conventional usage whenever they felt it right to do so.

Mann was and remained to the end a sturdy North countryman, retaining the accent and forthrightness of that hardy breed. His affection for his students did not prevent him from giving them a stern reprimand when he deemed it necessary. "He is bombarding" was the caution given by a student coming out from a lecture just ended to a group of students waiting to attend the next. But fow in the Indian Agricultural Service can have been better loved by the Indians than Harold Mann and his wife. Whon I was last in their region, I met some of his old students, who spoke of him almost with veneration and quoted many of his sayings. Yet he had been gone for twenty-four years. It is given to few to be remembered as long and with such deeply affectionate respect.

E. JoHN RUSSELI

\section{Dr. Olaf Hagerup}

Olaf Hagerup, who died on March 22, 1961, had onriched botanical science with many fruitful ideas and unusually stimulating and artistic pictures. $\mathrm{He}$ was born in 1889 as the son of a clorgyman in the Danish province of Jutland, where he was also brought up. He studied botany in the University of Copenhagen as the pupil of the four great professors, Johansen, Raunkiaer, Rosenvinge and Warming. He dofended his doctoral dissertation in December 1930 on a study of the morphology and systematics of the Cucurbitaceae. Shortly before his death he had retired from the post of superintendent of the Botanical Museum in Copenhagen.

Olaf Hagerup travelled widely in arctic and tropical regions and published a number of papers, some of which are elassics in their fields. He wrote papers on the morphology and anatomy of higher and lower plants, on taxonomy and distribution, on biological spectra and periodicity, on flower diagrams and fruit morphology. His best-known and certainly most important works are, however, on pollination, phylogeny and polyploidy, and it was mainly on the last subject that he published ideas that have had a wide influence. Among his last publications are two beautiful volumes, a botanical atlas, in which he, together with his friend Vagn Petersson, published magnificent drawings of almost all Danish plants. These volumes alone would be enough to perpetuate the names of their authors among botanists.

To some of his contemporaries, Dr. Hagerup may have been a quiet and religious day-dreamer who showed great artistic skill and an unusual ability for detailed observations. Others observed in him the great ideologist and thinker, who could spend long hours in developing unusually fortile ideas. It was, however, not in the nature of Dr. Hagerup himself to perform time-consuming and detailed studies to demonstrate ultimately the correctness of his ideas; this he willingly entrusted to others. Although many had observed the possible significance of chromosome numbers for taxonomy, he was the first to draw the cloar and logical taxonomical conclusions from cytological observations when, in 1927, he distinguished the tetraploid Empetrum hermaphroditum as a spocios separate from the diploid $E$. nigrum, and thus actually started the growing field of cytotaxonomy. It was also Hagerup who first, in 1932, put forward a clear hypothesis based on his observations of the difference in distribution of diploids and polyploids, an observa. tion that has greatly influenced geobotanical thinking, though explanations of this phenomenon still leave much room for further investigations.

Hagerup was known throughout the world for contributions that put him on a level with his four great teachers. Less known was his gentle kindness to others and his whole-hearted antipathy to all suppression of freedom, as became so evident during the Nazi occupation of his beloved country.

Olaf Hagerup was a keen artist and a natural philosopher of an unusual kind, and his wisdom made the visitor to his Museum or to his home feel that here was one of those fow gifted souls that prefor to enjoy Nature in peace and lot others pass undisturbed. He married Else Larsen, a student of botany and untiring co-worker, in 1935, by whom and their two daughters he is survived. Ásketc Löve

\section{NEWS and VIEWS}

\section{The Royal Society: Vice-Presidents}

THE following have been appointed vice-presidents for the year ending November 30: Lord Fleck, treasurer of the Royal Society and formerly chaiman of Imperial Chemical Industries Ltd.; Sir Lindor Brown, biological secretary of the Royal Society and Waynflete professor of physiology at the University of Oxford; Sir William Hodge, physical secretary of the Royal Society and Lowndean professor of geometry and astronomy in the University of Cambridge; Sir Patrick Linstead, foreign secretary of the Royal Society and rector of the Imperial College of Science and Technology; Prof. W. T. J. Morgan, deputy director of the Lister Institute and professor of biochemistry in the University of London; Sir Gordon Sutherland, director of the National Physical Laboratory.

\section{University of Leeds :}

Prof. F. G. Holliman

IN June 1961, the Council of the University established the post of director of combined studies in the Faculty of Soience, and it was agreed that the director would be responsible for the organization of a newly instituted degree course in which two science subjects are studied to a higher level. It was also envisaged that the director would take part in the 